\title{
Level of Overweight, Obesity and Associated Factors Among Preschool Children in Dire Dawa City, Eastern Ethiopia, 2016
}

\author{
Birhanu Ejara ${ }^{1} \quad$ Kefyalew Taye ${ }^{2}$ Takele Tiki ${ }^{3}$, \\ 1.MSC, Lecturer of Maternity and Reproductive health, \\ 2.MPH, Lecturers of Nutrition at Ambo University College of Medicine and Health Science, Ambo Ethiopia \\ 3. MSC in Psychiatry nursing at Ambo University College of Medicine and Health Science, Ambo Ethiopia
}

\begin{abstract}
Background: Obesity is accumulation of excess fat that have negative consequences on health. In $21^{\text {st }}$ century overweight and obesity of children is becoming burning issue. About 42 million under five children are overweight and obese in 2013. Close to 31 million of these are living in developing countries. The objective of this study was to assess the level of overweight and obesity and associated factors among preschool children aged 3-5years in Dire Dawa city, Ethiopia, 2016.

Methodology: A community based cross sectional study design was used from March 1-15 2016. Simple random sampling followed by systematic random sampling technique was used to select study participants. A pretested structured questionnaire was used to collect data from total samples of 627 preschool age children with their respective mothers or caretakers. Weight and height were measured using standardized and calibrated equipment. Finally Binary logistic regression analysis was done to identify factors associated with overweight and obesity. Level of statistical significance was declared at p- value less than 0.05 .

Results: The magnitude of overweight and obesity in the study area were $11.4 \%$ and $5.5 \%$ respectively. Female sex $(\mathrm{AOR}=2.67,95 \%$ CI: $1.13-6.32)$, Mother BMI $(\mathrm{AOR}=16.5,95 \%$ CI: $6.80-40.29$, p value $<0.001)$ and Father Education $(\mathrm{AOR}=7.179,95 \% \mathrm{CI}$ : $1.06-48.6$, $\mathrm{p}$ value $<0.05$ ) were among factors associated with preschool children overweight and obesity.

Conclusion and Recommendation: The combined prevalence of overweight and obesity seen in this city is $16.9 \%$. So as Government of Ethiopia continues in its fight towards reducing under nutrition, it should also expand or modify these efforts to include ways that may help prevent and reduce prevalence of overweight within the community.
\end{abstract}

Keywords: Overweight, Obesity, preschool children, Dire Dawa, Ethiopia.

DOI: $10.7176 / \mathrm{JMPB} / 52-06$

\section{BACKGROUND}

Obesity is defined as disproportionate or too much fat accumulation in our body that may impair health (WHO, 2015). It can be measured in different ways. For children, overweight and obesity are defined using age and sex specific monograms for body mass index (BMI). According to World Health Organization definition a child is defined as obese if BMI for Age Z-score is above $+3 \mathrm{SD}$ and overweight if Z-score is between $+2 \mathrm{SD}$ and $+3 \mathrm{SD}$ (WHO 2006).

The worldwide prevalence of preschool children overweight and obesity increased from $4.2 \%$ in 1990 to $6.7 \%$ in 2010. This trend is expected to reach $9.1 \%$, or ' 60 million, in 2020 . The estimated prevalence of preschool children overweight and obesity in Africa in 2010 was $8.5 \%$ and is expected to reach $12.7 \%$ in 2020(De Onis, Blo“ssner et al. 2010).

Obesity and overweight is once upon a time considered as a high income countries problem but now on the rise in low and middle income countries, particularly in urban settings. More than 30 million overweight children are living in developing countries compared to 10 million in developed countries (WHO 2013). According to the WHO estimates, the undernourished population in the world has declined and is roughly around 1.2 billion, whereas the over nourished population has increased to 1.2 billion (Sattar, Connachie et al. 2008).

Many low and middle income countries are now facing a "double burden" of disease. While they continue to deal with the problems of infectious disease and under nutrition, they are experiencing a rapid upsurge in non communicable disease risk factors such as obesity and overweight, particularly in urban settings. It is not uncommon to find under nutrition and obesity existing side by side within the same country, the same community and the same household (WHO 2015).

Overweight and obesity among preschool children has received worldwide attention, partly in response to concerns about the increasing prevalence of obesity globally and partly as a result of the association between early childhood obesity and the long term increases in mortality and morbidity. (Al-Raees, MA. et al. 2009)

Overweight and obesity are the fifth leading risk for global deaths. At least 2.8 million adults die each year as a result of being overweight or obese. In addition, $44 \%$ of the diabetes burden, $23 \%$ of the ischemic heart disease burden and between $7 \%$ and $41 \%$ of certain cancer burdens are attributable to overweight and obesity. Overweight children are more than twice as likely to have high blood pressure or heart disease as children of normal weight 


\section{(WHO 2008)}

Other issue for obesity of preschool age children attention is issue of adiposity rebound. BMI or adiposity rebound refers to a period, usually between 4 and 7 years of age, when BMI reaches a nadir and then begins to increase throughout the rest of childhood, adolescence, and young adulthood. Even once obesity is established in children (as in adults) it is hard to reverse (De Onis, Blo"ssner et al. 2010). Hence obese child is more likely to be obese adult as compared to normal child; intervention during early life stage is beneficiary (Daniels, Arnett et al. 2005).

In Ethiopia, most studies were dealing with under nutrition than over nutrition due to the major problem of the country was under nutrition. But now days due to nutrition transition over nutrition is becoming public problem in urban areas. So that over burden the country both with over nutrition and under nutrition.

\section{METHODES AND MATERIALS}

2.1. Study Area and Period: Dire Dawa is one of two chartered cities in Ethiopia located at $515 \mathrm{~km}$ East of Addis Ababa, the capital city of Ethiopia. Based on the 2007 Census conducted by the Central Statistical Agency of Ethiopia (CSA), Dire Dawa has a total population of 341,834, of whom 171,461 are men and 170,461 women and 233,224 or $68.23 \%$ of the population are urban inhabitants. It is organized under 38 rural and 9 urban Kebeles. The total under five children in this city constitutes about 41628 . Finally this study was conducted from January 2015 to February 2016 in Dire Dawa city administration.

2.2. Study Design, Sample Population and sample size determination: community based cross-sectional study design was used. Randomly selected children aged 3-5years and their mothers or care takers in randomly selected kebele's of Dire Dawa City Administration were study subjects. Mothers or care takers who have been living permanently at least for six months in the study area having Preschool children aged 3-5years were included in this study whereas children with chronic illness, visible physical deformity and edema were excluded from this study as such factors may distort anthropometric measurements.

Sample size for the first objective (prevalence of overweight and obesity) was estimated based on single population proportion formula $\left(\mathrm{n}=(\mathrm{Z} \alpha / 2)^{2} \mathrm{pq} / \mathrm{d} 2\right)$ considering confidence level at $95 \%=1.96$, margin of error $(\mathrm{d})$ $=0.05$ and $p=0.073$ from previous study done in Hawassa city in 2014, (Wolde and Belachew 2014). Sample size for the second objective (associated factors) was calculated by using Epi-info 7 statistical software considering different factors associated with children overweight and obesity in previous study. Finally when we compare sample size calculated for first objective (120) and for second objective (418) the second one is the largest and considering 1.5 design effects on the largest sample size, the final sample 627 was studied.

2.3. Sampling Procedure and Data Collection: First three kebeles (kebele refers to the lowest administrative unit) in Dire Dawa city were selected randomly by lottery method. Then study subjects were allocated to selected kebeles proportion to population size based on number of preschool age children found in each kebeles. Finally systematic random sampling was used to reach at households containing eligible study subjects using house numbers. The first house containing eligible subject was obtained by Lottery method. Data was collected by using face-to-face interviewer administered questionnaire. The data collectors were trained 3 Diploma Nurses and 3 Health extension workers mean while supervision was done by 3 Health Officers. Anthropometric measurements were taken by standardized and calibrated equipments. Height was measured making the child barefoot, in light clothing and remove any pins and braids from the hair that could affect the measurement. Height then recorded to the nearest $0.1 \mathrm{~cm}$ and positioning the subject at the Frankfurt plane using a stadiometer seca (Germany). Weight measured children with light clothing and recorded to the nearest $0.1 \mathrm{~kg}$ using UNICEF seca digital weighing scale (Germany) (Gibson, 2005). Age of the child was asked from both the child's date of birth and age on the day measured, and then the mothers or care takers were probed to report the correct age. Finally the age calculated by subtracting date of birth from date of data collection (WHO 2009). Finally WHO 2006 growth reference standards, was used to transform children's weight and height measurements into sex and age specific Z-score (i.e. BMI-forage Z-score BAZ)

\subsection{Operational Definitions}

$>$ Non Overweight and non obese was defined as proportion of preschool children with values Body mass Index for age Z score (BAZ) $<2$ Standard Deviation (SDs).

$>$ Over weight and obese was defined as proportion of preschool children with values BAZ $\geq 2$ SDs.

> Maternal BMI can be classified based on international cut-off point as follows. Underweight was defined as BMI $<18.5 \mathrm{~kg} / \mathrm{m} 2$ normal body weight was defined as BMI $=18.5-24.9 \mathrm{~kg} / \mathrm{m} 2$, overweight as defined as BMI $=25.0-29.9 \mathrm{~kg} / \mathrm{m} 2$ and obese was defined as BMI $\geq 30.0 \mathrm{~kg} / \mathrm{m}$ (WHO 2006).

$>$ Physical activity in children was defined as playing out door games $\geq 1$ hour per day.

$>$ Screen time was defined as watching TV, DVD or playing computer game $\geq 2$ hours per a day (Barlow, 2007). 
$>$ Dietary diversity score (DDS) was categorized as high, medium and low for score of $>6$ DDS, 3-5 DDS and $<3$ DDS respectively (here giving score of 1 for Yes and 0 for No to each question of DDS) (Wolde and Belachew 2014).

2.5. Data Quality Control: the questionnaire was translated into the local languages. Two days of training was provided to the data collectors and supervisors. The questionnaire was pretested on $5 \%$ of the sample size. Data collectors were closely supervised. Completeness of each questionnaire was checked. All anthropometric measurements were measured by three trained Diploma nurses and Relative TEM calculated to check intra observer variability. Weight scale was calibrated to zero level with no object on it and placed in level surface before measurement performed. The scales of measurements were checked continuously for their reliability. Finally, multivariate analysis was conducted to control the confounding factors.

2.6. Data Processing and Analysis: The data were checked for completeness and consistency before entered to computer. Then it was coded and entered in the computer using EPI-DATA 3.1 software and then sex, age, height and weight transferred with ID number to WHO Anthros version 3.1.0 software to convert nutritional data into Zscores of the indices; BAZ using new WHO growth standard reference. Then entered data were transformed to SPSS version 20 for further analysis and descriptive summary like frequency, proportion, cross tabs and graphical presentation.

Initially the analysis of data was done by using bivariate logistic Regression to determine association between dependent variable and predictors. Here the association was checked by crude odds ratio and $95 \%$ CI. Then significant variable ( $\mathrm{p}$ value $\leq 0.3$ ) obtained by bivariate analysis included in multivariable analysis. Hosmerlemeshow test $(>0.05)$ and multicollinearity checked $(\mathrm{VIF}<3)$ before proceeding multivariate analysis. Adjusted Odd ratios, along with $95 \% \mathrm{CI}$, were estimated to identify factors associated with overweight and obesity using multivariable logistic regression analysis. Level of statistical significance was declared at $\mathrm{P}$-value $<0.05$.

\subsection{Ethical considerations}

The study was reviewed and approved by the Institutional Health Research Ethics Review Committee (IHRERC) of Haramaya University of Ethiopia. Informed written consent was obtained from parents or caregivers. Child assent was taken for anthropometric measurements. Confidentiality of information collected from each study participant was not disclosed. Health education and medical advice was given for family as well as obese and overweight child.

\section{RESULTS}

In this study data were collected from 590 children aged 3-5years and their respective mothers/care givers with response rate of $94 \%$. Thus the collected data were used to determine the prevalence and factors associated with overweight and obesity in the study area.

\subsection{Socio- economic and demographic characteristics of study participants}

Among study participants 40.2\% were Muslims, 28\% were orthodox and $14.2 \%$ were protestant by their religion. Majorities of mothers were house wife (70\%) followed by merchant (13.4\%) and government employ (11.2\%) whereas the majorities of fathers were merchant $(34.9 \%)$ followed by government employ $(30.9 \%)$ and farmers $(19.2 \%)$ respectively. About $48 \%$ fathers and $31.4 \%$ mothers joined collage/ University and above whereas about $5.6 \%$ mothers and $3.9 \%$ mothers were unable to read and write (see Table 1). 
Table 1: Socio- demographic characteristics of preschool children, Dire Dawa, Ethiopia 2016. $(\mathbf{n}=590)$

\begin{tabular}{|c|c|c|c|}
\hline Variable & & Frequency & Percent (\%) \\
\hline Sex of child & & & \\
\hline Male & Female & 278 & 47.1 \\
\hline & & 312 & 52.9 \\
\hline Age of child(in months) & & & \\
\hline $36-47$ & & 340 & 57.6 \\
\hline $48-60$ & & 250 & 42.4 \\
\hline Educational status of child & & & \\
\hline Not enrolled to $\mathrm{KG}$ & & 307 & 52 \\
\hline $\mathrm{KG}$ and above & & 283 & 48 \\
\hline Parental educational status ( & & & \\
\hline$\leq$ Grade 4 & & $123(84)$ & $20.8(14.2)$ \\
\hline Grade 5-8 & & $79(75)$ & $13.4(12.7)$ \\
\hline Grade $9-12$ & & $204(148)$ & $34.6(25)$ \\
\hline Collage / university & & $184(283)$ & $31.2(48)$ \\
\hline Occupation of mother & & & \\
\hline House wife & & 417 & 70.6 \\
\hline Government employ & & 95 & 16.1 \\
\hline Merchant & & 79 & 13.4 \\
\hline Occupation of father & & & \\
\hline Government employ & & 182 & 30.8 \\
\hline Farmer & & 113 & 19.2 \\
\hline Merchant & & 206 & 34.9 \\
\hline Daily laborer & & 44 & 7.5 \\
\hline Meson & & 20 & 3.5 \\
\hline Other & & 24 & 4 \\
\hline Religion & & & \\
\hline Orthodox & & 165 & 28 \\
\hline Muslim & & 237 & 40.2 \\
\hline Protestant & & 84 & 14.2 \\
\hline Catholic & & 64 & 10.8 \\
\hline Others & & 40 & 6.8 \\
\hline Family size & & & \\
\hline$<5$ & & 330 & 55.9 \\
\hline$\geq 5$ & & 260 & 44.1 \\
\hline Household monthly income & & & \\
\hline$<1500 \mathrm{EBR}$ & & 139 & 23.6 \\
\hline$\geq 1500 \mathrm{EBR}$ & & 451 & 76.4 \\
\hline
\end{tabular}

$\mathrm{M} / \mathrm{F}$ indicates mother and father respectively ,others *driver, wakefata,

\subsection{Child feeding practices}

In this study only about $84 \%$ of the children were exclusively breastfed among whom $57.5 \%, 40.9 \%$ and $1.6 \%$ fed for the first four months, for the first six months and greater than six months respectively. Altogether 52.5\% continued BF for $<12$ months, $28 \%$ for $12-18$ months and 3.6\% for 19-24 months. Regarding infant formula feeding about $63.2 \%$ fed formula in which $25.2 \%$ of them started during the early infancy $0-3$ months while $40.2 \%$ and $34.6 \%$ started during 4-6 months and $>6$ months respectively.(Table 2) 
Table 2: Feeding practices of preschool age children aged 3-5yrs in Dire Dawa City, Ethiopia 2016. (n=590)

\begin{tabular}{|c|c|c|}
\hline Variables & Frequency & Percent \\
\hline \multicolumn{3}{|c|}{ Exclusive Breastfeeding (minimum for 4 months ) } \\
\hline Yes & 496 & 84.1 \\
\hline No & 94 & 15.9 \\
\hline \multicolumn{3}{|l|}{ Duration of exclusive breastfeeding } \\
\hline The first 4 months & 285 & 57.5 \\
\hline The first 6 months & 203 & 40.9 \\
\hline$>6$ months & 8 & 1.6 \\
\hline \multicolumn{3}{|l|}{ Duration of continued breastfeeding } \\
\hline$<12$ months & 310 & 62.5 \\
\hline $12-18$ months & 165 & 33.3 \\
\hline 19-24 months & 21 & 4.2 \\
\hline \multicolumn{3}{|l|}{ Infant formula feeding } \\
\hline Given & 373 & 63.2 \\
\hline Not given & 217 & 36.8 \\
\hline \multicolumn{3}{|l|}{ Age of started infant formula } \\
\hline $0-3$ months & 94 & 25.2 \\
\hline 4-6 months & 150 & 40.2 \\
\hline$>6$ months & 129 & 34.6 \\
\hline \multicolumn{3}{|l|}{ Duration of infant formula } \\
\hline 0-3 months & 67 & $17.9 \%$ \\
\hline 4-11 months & 125 & 33.5 \\
\hline$>12$ months & 181 & 48.6 \\
\hline
\end{tabular}

\subsection{Dietary diversity score by preschool children}

The Dietary Diversity Score of preschool children in the study area were reported by mothers/care takers in the last 24 hours. Most Fruits and vegetables were available in the market in the area from March to April and October to February respectively. The minimum and maximum DDS were 1 and 8 respectively with mean $( \pm S D)$ score of $3.57 \pm 1.63$. Foods from grains, tubers and roots were consumed by majorities $(67.6 \%)$ whereas meat, poultry, fish and sea foods were least consumed (32.7\%) food groups in this study (Table 3 )

Table 3: proportion of preschool children aged 3-5yrs who consume different food groups in the last 24 hours preceding the date of survey in Dire Dawa City, $2016(n=590)$

\begin{tabular}{lll}
\hline Food groups & $\begin{array}{l}\text { Frequency } \\
\text { (yes) }\end{array}$ & $\begin{array}{c}\text { Percent } \\
\text { Foods made from grains, roots and tubers }\end{array}$ \\
Vitamin A-rich fruits and vegetables & 399 & 67.6 \\
Other vegetables and fruits & 266 & 45.1 \\
Meat, poultry, fish and sea foods & 287 & 48.6 \\
Eggs & 193 & 32.7 \\
Food made from pulses, legumes and nuts & 249 & 42.2 \\
Milk and milk products & 250 & 42.4 \\
Foods cooked in oil/fat/butter or sweat foods and drinks (soft drinks, Halawa, & 217 & 42 \\
baqlawa, mushabek...) & 248 & 36.8 \\
Children diet diversity score mean \pm SD & $\mathbf{3 . 5 7} \pm \mathbf{1 . 6 3}$ & \\
\hline
\end{tabular}

\subsection{Food frequency patterns by preschool children.}

Food frequency pattern was collected from mothers/care givers in the last 30 days prior to the actual data collection. Majorities of the children about 35\% consumed foods made of cereals and grains like Injera, bread, macaroni, and pasta more than once per day while $31.4 \%$ of them consume once per a day. Eggs and fish are least frequently consumed foods about $0.5 \%$ consumed once per a day. (Table 4 ) 
Table 4: Food frequency patterns by preschool children aged 3-5yrs in the last one month prior to survey in Dire Dawa City, Ethiopia $2016(\mathbf{n}=590)$.

\begin{tabular}{|c|c|c|c|c|c|c|}
\hline $\begin{array}{l}\text { Frequency of food } \\
\text { groups }\end{array}$ & $\begin{array}{l}\text { More than once } \\
\text { per day }\end{array}$ & $\begin{array}{l}\text { Once per } \\
\text { day }\end{array}$ & $\begin{array}{l}\text { 3-6 times } \\
\text { per } \\
\text { week }\end{array}$ & $\begin{array}{l}\text { Once/twice } \\
\text { per week }\end{array}$ & $\begin{array}{l}\text { Twice per } \\
\text { month/less }\end{array}$ & Never \\
\hline & No $(\%)$ & No $(\%)$ & No $(\%)$ & No $(\%)$ & No (\%) & No (\%) \\
\hline Cereals and grains & $207(35)$ & $181(31.4)$ & $97(16.4)$ & $84(14.2)$ & $15(2.5)$ & $2(3)$ \\
\hline Roots and tubers & $62(10.5)$ & $97(16.4)$ & $208(35.3)$ & $144(23.9)$ & $77(13.1)$ & $5(8)$ \\
\hline Vegetables & $25(4.2)$ & $60(10.2)$ & $152(25.8)$ & $187(31.7)$ & $124(21)$ & $42(7.1)$ \\
\hline Fruit & $16(2.7)$ & $55(9.3)$ & $110(18.6)$ & $157(26.6)$ & $197(33.4)$ & $55(9.3)$ \\
\hline Meat & $8(1.4)$ & $30(5.1)$ & $86(14.6)$ & $128(21.7)$ & $255(43.2)$ & $83(14.1)$ \\
\hline Eggs & $3(0.5)$ & $33(5.6)$ & $59(10)$ & $88(14.9)$ & $259(43.9)$ & $148(25.1)$ \\
\hline Fish & $2(0.5)$ & $7(12)$ & $26(4.4)$ & $21(3.6)$ & $137(23.2)$ & $397(67.3)$ \\
\hline $\begin{array}{l}\text { Milk and milk } \\
\text { products }\end{array}$ & $5(8)$ & $20(3.4)$ & $50(8.5)$ & $71(12)$ & $250(42.4)$ & 194(32.9) \\
\hline Sweat foods & $124(21)$ & $249(42.2)$ & $114(19.3)$ & $18(3.1)$ & $78(13.2)$ & $7(1.2)$ \\
\hline Soft drinks & $10(1.7)$ & $24(4.1)$ & $139(23.6)$ & $269(45.6)$ & $68(11.5)$ & $80(13.6)$ \\
\hline $\begin{array}{l}\text { Food cooked with } \\
\text { oil, fat or butter }\end{array}$ & $87(14.7)$ & $153(25.9)$ & $220(37.3)$ & $16(2.7)$ & $36(6.1)$ & $78(13.2)$ \\
\hline
\end{tabular}

\subsection{Sedentary behavior and physical activities of preschool children}

As described in the table below, sedentary behaviors of preschool children were assessed by asking screen time (TV, DVD and computer use). In this study majorities (66.9 \%) view television among whom only $28.1 \%$ view greater than or equal to 2 hours per day. Children who play computer and mobile game constitutes $39 \%$ of total sample, among whom only $23 \%$ played greater than or equal to 2 hours per day. Regarding physical activities, the majorities about $91 \%$ play outdoor games, among whom $36.9 \%$ play less than 1 hour per day. (Table 5)

Table 5: Sedentary behavior and physical activities of preschool children aged 3-5 years in Dire Dawa city, Ethiopia 2016. $(\mathbf{n}=590)$

\begin{tabular}{|c|c|c|}
\hline Variables & Frequency & Percent \\
\hline \multicolumn{3}{|l|}{ Television viewing (DVD, Video) } \\
\hline$<2$ hours per day & 284 & 71.9 \\
\hline$\geq 2$ hours per day & 111 & 28.1 \\
\hline \multicolumn{3}{|l|}{ Computer game } \\
\hline$<2$ hours per day & 177 & 77 \\
\hline$\geq 2$ hours per day & 53 & 23 \\
\hline \multicolumn{3}{|l|}{ Physical exercise(outdoor game) } \\
\hline$<1$ hours per day & 218 & 36.9 \\
\hline$\geq 1$ hours per day & 319 & 54.1 \\
\hline \multicolumn{3}{|l|}{ Active transport } \\
\hline$<5$ days per week & 541 & 91.7 \\
\hline$\geq 5$ days per week & 49 & 8.3 \\
\hline
\end{tabular}

\subsection{Factors associated with overweight and obesity}

In this study, variables that are linked to overweight and obesity the first step analysis were child sex, monthly income, maternal BMI, father education, mother occupation, DDS, child age in months, duration of EBF, screen time and maternal estimation of her child weight status. In the second step analysis, all variables that show association in bivariate analysis were included in multivariable analysis. (Table 6)

There was a significant association between overweight $\&$ obesity and child sex. Female preschool children 
were 2.67 times more likely to be overweight and obese as compared to male (AOR = 2.67, 95\% CI: $1.13-6.32$, $\mathrm{p}$ value $<0.05)$. Similarly strong association was seen between preschool children overweight $\&$ obesity and maternal body mass index. Children from overweight and obese mothers were 16.5 times more likely to be overweight and obese as compared to children from non overweight and non obese mothers (AOR $=16.5,95 \%$ CI: $6.80-40.29$, p value $<0.001)$ (Table 6).

Father educational status was also associated with child overweight and obesity. The odds of being overweight and obese was 7 times higher for children whose father was less than or equal to grade four compared to children whose father have completed collage/University (AOR $=7.179,95 \% \mathrm{CI}$ : 1.06-48.6, $\mathrm{p}$ value $<0.05$ ). Duration of exclusive breast feeding was also another factor linked to preschool children overweight and obesity. The odds of being overweight and obese was 2.4 times higher for children who fed only for the first 4 months compared to children who fed for the first 6 months (AOR =2.4, CI: 1.02- 5.74, p <0.05) (Table 6).

Table 6: Bivariate and Multivariable logistic regression analysis predicting the likelihood of preschool children in Dire Dawa City to be overweight and obese, $2016(\mathrm{n}=590)$

\begin{tabular}{|c|c|c|c|c|c|}
\hline Variables & $\begin{array}{l}\text { Frequency } \\
(\%)\end{array}$ & $\begin{array}{l}\text { Overweight } \\
\text { \&obese } \\
\text { (No) }\end{array}$ & $\begin{array}{l}\text { Non over } \\
\text { weight and } \\
\text { non } \\
\text { obese(No) } \\
\end{array}$ & $\begin{array}{l}\text { Crude OR }(95 \% \\
\text { CI) }\end{array}$ & $\begin{array}{l}\text { Adjusted OR } \\
(95 \% \text { CI })\end{array}$ \\
\hline $\begin{aligned} \text { Child sex } & \text { Male } \\
& \text { Female }\end{aligned}$ & $\begin{array}{l}278(47.1) \\
312(52.9)\end{array}$ & $\begin{array}{l}24 \\
44\end{array}$ & $\begin{array}{l}254 \\
268\end{array}$ & $\begin{array}{l}1 \\
0.57(0.34-0.97)^{*}\end{array}$ & $\begin{array}{l}1 \\
2.67(1.13-6.32) *\end{array}$ \\
\hline $\begin{array}{c}\text { Monthly income } \\
>1500 \\
<1500 \\
\end{array}$ & $\begin{array}{l}451(76.4) \\
139(23.6) \\
\end{array}$ & $\begin{array}{l}60 \\
8 \\
\end{array}$ & $\begin{array}{l}391 \\
131 \\
\end{array}$ & $\begin{array}{l}2.5(1.17-5.39)^{*} \\
1\end{array}$ & $\begin{array}{l}1.14(.22-5.94) \\
1\end{array}$ \\
\hline $\begin{array}{c}\text { Mother occupation } \\
\text { Housewife } \\
\text { Gov't employ } \\
\text { Merchant }\end{array}$ & $\begin{array}{l}417(70.6) \\
95(16.1) \\
79(13.4)\end{array}$ & $\begin{array}{l}41 \\
8 \\
19 \\
\end{array}$ & $\begin{array}{l}376 \\
86 \\
60 \\
\end{array}$ & $\begin{array}{l}1 \\
0.38(0.33-1.88) \\
2.9(1.58-5.33)^{* *}\end{array}$ & $\begin{array}{l}1 \\
0.84(0.23-3.02) \\
1.4(0.5-4.1)\end{array}$ \\
\hline $\begin{array}{l}\text { Child age } \\
36-47 \text { months } \\
48-60 \text { months } \\
\end{array}$ & $\begin{array}{l}340(57.6) \\
250(42.4) \\
\end{array}$ & $\begin{array}{l}44 \\
24 \\
\end{array}$ & $\begin{array}{l}296 \\
226 \\
\end{array}$ & $\begin{array}{l}1 \\
1.39(0.82-2.37) \\
\end{array}$ & $\begin{array}{l}1 \\
0.63(.27-1.49)\end{array}$ \\
\hline $\begin{array}{l}\text { Father education } \\
\leq \text { Grade } 4 \\
\text { Grade } 5-8 \\
\text { Grade } 9-12 \\
\text { Collage/university }\end{array}$ & $\begin{array}{l}84(14.2) \\
75(12.7) \\
148(25) \\
283(47.9) \\
\end{array}$ & $\begin{array}{l}18 \\
11 \\
20 \\
19 \\
\end{array}$ & $\begin{array}{l}66 \\
64 \\
128 \\
264 \\
\end{array}$ & $\begin{array}{l}1.28(0.59-2.78) \\
1.63(0.76-3.45) \\
1.4(0.8-2.74) \\
1\end{array}$ & $\begin{array}{l}7.1(1.06-48.6)^{* *} \\
1.2(1.61-3.92) \\
1.1(0.5-1.96) \\
1\end{array}$ \\
\hline $\begin{array}{c}\text { Duration of EBF } \\
1^{\text {st }} 4 \text { months } \\
1^{\text {st }} 6 \text { months } \\
\end{array}$ & $\begin{array}{l}285(57.5) \\
211(42.5) \\
\end{array}$ & $\begin{array}{l}26 \\
33 \\
\end{array}$ & $\begin{array}{l}259 \\
178 \\
\end{array}$ & $\begin{array}{l}0.6(0.31-1.16)^{*} \\
1\end{array}$ & $\begin{array}{l}2.4(1.05-5.74)^{*} \\
1\end{array}$ \\
\hline $\begin{array}{l}\text { TV ,DVD, Video } \\
\text { viewing } \\
\quad \geq 2 \text { hours } \\
\quad<2 \text { hours }\end{array}$ & $\begin{array}{l}111(18.8) \\
284(48.1) \\
\end{array}$ & $\begin{array}{l}17 \\
31 \\
\end{array}$ & $\begin{array}{l}94 \\
253 \\
\end{array}$ & $\begin{array}{l}1.47(.78-2.79) \\
1\end{array}$ & $\begin{array}{l}1.08(.41-2.82) \\
1\end{array}$ \\
\hline $\begin{array}{r}\text { Mother BMI } \\
\geq 25 \\
<24.99 \\
\end{array}$ & $\begin{array}{l}55(9.3) \\
535(90.7) \\
\end{array}$ & $\begin{array}{l}31 \\
37 \\
\end{array}$ & $\begin{array}{l}24 \\
498 \\
\end{array}$ & $\begin{array}{l}17.3(9.2-32.6) \\
1\end{array}$ & $\begin{array}{l}16.5(6.8-40.2)^{* *} \\
1\end{array}$ \\
\hline $\begin{array}{l}\text { DDS } \\
\quad \text { Low } \\
\text { Medium } \\
\text { High } \\
\end{array}$ & $\begin{array}{l}145(24.6) \\
391(66.3) \\
54(9.2)\end{array}$ & $\begin{array}{l}14 \\
42 \\
12 \\
\end{array}$ & $\begin{array}{l}131 \\
349 \\
42 \\
\end{array}$ & $\begin{array}{l}0.37(.16-.87)^{*} \\
0.42(.21-.86) \\
1\end{array}$ & $\begin{array}{l}0.91(.22-3.70) \\
0.59(.20-1.77) \\
1\end{array}$ \\
\hline
\end{tabular}

Key: The asterisks * shows $\mathrm{p}$ value $<0.05$ and $* *$ shows $\mathrm{p}$-value $<0.001$

\section{DISCUSSION}

The present study analysis demonstrates that the combined prevalence of overweight and obesity among preschool children aged 3-5 years in Dire Dawa city was 16.6\%, of which 11.1\% (95\% CI: 8.2-11.9) \& 5.5\% (95\% CI: 4.76.8) were overweight and obese respectively. This finding can be comparable with other studies from developed and developing countries. For instance in Kingdom of Bahrain (Middle East) the prevalence of overweight and obesity were $12.3 \%$ and $8.4 \%$ (Al-Raees, MA. et al. 2009). Similarly in Ghana Accra about $10.9 \%$ and $7.2 \%$ preschool children were overweight and obese respectively (Mohammed and Vulvor 2012). These findings are little bit higher than the result of this study. The discrepancy may be attributed to children in this study area were 
living in countries less adapted to nutritional transition. Likewise the prevalence of overweight was about $27.3 \%$ in Serbian Preschool Children who enrolled to Kindergartens (Ostojic, Stojanovic et al. 2012) which was more than double times higher than the result of this study. The possible reason for the difference may be socio economic variation among the two countries (i.e. Ethiopia in SSA \& Serbia in Europe).

The prevalence of overweight and obesity in Basrah (Iraq) were 7.6\% and 3.6\% respectively which is lower than the finding of this study (Musa and Hassan 2010). One reason may be time gap between this study and the previous study and there may be good prevention strategies against childhood overweight and obesity in middle income countries than SSA country like Ethiopia.

According to review article by VanHook, Altmana et al. 2013, the prevalence of overweight and obesity in SSA ranges from $5.3 \%$ in Bangladesh to $41 \%$ in Armenia. The result of this study was in the range stated, even though the stated range was very wide and the review was conducted few years back (1990-2008).

When compared to the national data of Ethiopia, the current prevalence of overweight and obesity was much higher than EDHS 2011 report. Overall, 2 percent of children below age five years were overweight or obese. But for Addis Ababa, 6 percent of children under five, the highest percentage in all regions, were overweight or obese. Generally the prevalence variation may be attributed to fast socioeconomic development in the country.

According to this study the prevalence of overweight and obesity were $8.5 \% \& 4.4 \%$ for boys and $13.9 \% \&$ $6.5 \%$ for girls respectively. And this disparity was statistically significant where girls were 2.67 times more likely to be overweight and obese as compared to boys ( $\mathrm{AOR}=2.67,95 \% \mathrm{CI}: 1.13-6.32$, p value $<0.05$ ). Similar results have been reported from Ghana, girls were more likely to be overweight and obese as compared to boys ( $\mathrm{p}$ value $<0.001$ ) (Mohammed and Vuvor 2012), additionally from Egypt about $6.1 \%$ girls and 4.7\% boys were obese and this was also shown statistically significant $(A O R=1.32, p$ value $<0.001)$ (Safiya, Shaker et al. 2014).

In contrast, studies from Iran showed that the prevalence of overweight was higher in boys (23.6\%) than girls $(19.3 \%)$ and this difference was statistically significant $(\mathrm{p}=0.001)$ (Tabesh, Hosseiny et al. 2014). In addition to this a pocket study in Hawassa city, South Ethiopia also reported that the prevalence of overweight and obesity was higher among boys $9 \%$ and 3.4\% while in girls 5.5\% and 3.3\%,respectively (Wolde and Belachew 2014). But when compared to the present study prevalence of overweight and obesity of both sex reported in Hawassa city was smaller than this result. The variation seen in these studies may be attributed to difference in screen time (TV, DVD) of participants. In this study about $39 \%$ girls and $19 \%$ boys had screen time greater than 2 hrs per day. Other possible explanation may be time gap between this study and the previous.

In this study maternal BMI was associated with preschools' children overweight and obesity. The odds of being overweight and obese was 16 times more likely for children from overweight and obese mothers compared to children from non overweight and non obese mothers (AOR $=16.5,95 \% \mathrm{CI}: 6.80-40.29$, $\mathrm{p}$ value $<0.001$ ). Similar result have been reported from China which found that maternal BMI was significantly associated with offspring elevated BMI ( $\beta=0.134, \mathrm{P}=.002)$ (McCarthy, Ye et al. 2015). In addition study from America also stated that there was strong association between maternal BMI and child elevated weight status than father BMI (Whitaker, Jarvis et al. 2010).

In the present study father educational status was significantly associated with preschool children overweight and obesity $(\mathrm{p}<0.05)$. About $27 \%$ overweight and obese children belongs to father who learned up to grade four, while only about $7.2 \%$ overweight and obese children belongs to Collage/University completed fathers. Similar result have been reported from Ghana, increase in parental educational level was associated with decrease in overweight/obesity of children $(B=-0.242$, $p$-value=0.043) (Mohammed and Vuvor 2012). The possible explanation may be increased paternal educational status has been associated with enhanced acquisition and use of health knowledge and health services, affects preference to child health and family size as well as healthy life styles.

Conversely, study from Western Algeria stated that higher parental education is predictor of childhood overweight $(\mathrm{p}<0.001)$ (Saker, Merzouk et al. 2011) and from Egypt More than half of obese children belongs to university educated fathers $(54.9 \%)$ while about $60.5 \%$ normal children belongs to pre University educated fathers (Safiya, Shaker et al. 2014). This might be attributed to cultural influence posed on fathers in these countries to make decision on child health issues.

Regarding breast feeding, duration of Exclusive breastfeeding was one of the factors associated with preschool children overweight and obesity. Children who exclusively breastfed only for the first 4 months were more likely to be overweight and obese, than those who exclusively breastfed for the first 6 months $(p<0.05)$. In support to this finding, a review of about 9000 articles in England reports, breastfeeding had a protective effect against obesity (Ip, Chung et al. 2007). The reason might be the smaller the duration of EBF the earlier the children could start either formula or complementary feeding which may be then a risk for childhood overweight and obesity.

This study is limited by the fact that Body Mass Index was used to measure body fat in these children. The waist circumference or Waist/Hip ratios are better tools to measure the health impact of excess fat. Food frequency questionnaires rely on memory of the respondents and were not validated. Furthermore this study had also strength 
like taking anthropometric measurement twice, using TEM to identify intra observer variability of measurement errors and probing the respondents to get valid information.

In conclusion the prevalence of overweight and obesity was $11.4 \% \& 5.5 \%$ respectively. The factors that have been identified as predictors of preschool children overweight and obesity were child sex, mother BMI, father education and duration of exclusive breast feeding. So that the government should expand or modify efforts to include ways that may help prevent and reduce prevalence of overweight within the community.

\section{LIST OF ABBREVIATION}

\section{Declaration}

$\begin{array}{ll}\text { BAZ } & \text { Body mass index for age z score } \\ \text { BMI } & \text { Body mass index } \\ \text { DBM } & \text { Double burden of malnutrition } \\ \text { DDS } & \text { Dietary diversity score } \\ \text { DEXA } & \text { Dual energy x-ray absorption } \\ \text { EMR } & \text { East Mediterranean Region } \\ \text { EDHS } & \text { Ethiopian demographic and health survey } \\ \text { FFQ } & \text { Food frequency questionnaires } \\ \text { HEWs } & \text { Health extension workers } \\ \text { IHRERC } & \text { Institute of health research and ethics review committee } \\ \text { MRI } & \text { Magnetic resonant imaging } \\ \text { SRS } & \text { Simple random sampling } \\ \text { SPSS } & \text { Statistical package for social science } \\ \text { VIF } & \text { Variance Inflation Factor }\end{array}$

Ethics approval and consent to participate: The study was reviewed and approved by the Health Research Ethics Review Committee of Haramaya University of Ethiopia. Informed written consent was obtained from parents or caregivers. Confidentiality of information collected from each study participant was not disclosed.

Consent to publish: All authors have read the content of the manuscript and had common understanding regarding the finding of the study. They also have agreement to publish it under this journal.

Availability of data and materials: all data regarding this study is available and it can be send up on request.

Competing interests: The authors also declare that there are no any other financial or non-financial competing interests.

Funding: The author did not receive payments, funding, or salary from any organization in relation to the work and publication of this paper. There is no any organization affected positively or negatively by the publication of this paper.

Author's contribution: BE and KT guide proposal preparation, data collection and assists final report writing. TT conceptualized the research question, analyzed and interpreted the findings. All Authors have read the manuscript and had common understanding regarding the study.

\section{Acknowledgement}

We are grateful to Dire Dawa city Administration along with dwellers of Addis Ketema, Sabian and Laga Harre kebele's and all our study participants.

\section{REFERENCES}

1. Al-Raees, Al-Amer MA,Musaiger, AO and D'Souza, R.(2009). "Prevalence of overweight and obesity among children aged 2-5 years in Bahrain: A comparison between two reference standards." Inter J pedia Obes 4: 414-416.

2. Alawi, S. Abdulatif, Abdulatif, F.Al Dhubaib, D. Mohammed, H. Al Ansari, A. (2013). Prevalence of overweight and obesity across preschool children from four cities of the Kingdom of Bahrain " International Journal of Medical Science and Public Health 2(2): 507-510.

3. Anderson, S. Economos, C.D. Must, A (2008). "Active play and screen time in US children aged 4 to 11 years in relation to sociodemographic and weight status characteristics: a nationally representative crosssectional analysis" BMC Public Health 8(366).

4. Azadbakht, L, Mirmiran, P.Azizi, F. (2005). "Dietary diversity score is favorably associated with the metabolic syndrome in Tehranian adults." International Journal of Obesity (2005) 29, 1361-1367 29: 13611367.

5. Baird, J. Fisher, D.Lucas, P.(2005). "Being big or growing fast: systematic review of size and growth in infancy and later obesity." BMJ(331): 929-934.

6. Barker, D. (2006). "In utero programming of cardiovascular disease" International Journal of Animal 
Reproduction 53(2): 555-573.

7. Barlow. S.E.Expert committee recommendations regarding the prevention, assessment, and treatment of child and adolescent overweight and obesity: summary report. Pediatrics 2007, 120(Suppl 4):164-192

8. Branca, F.Nikogosian, H. Lobstein, T. (2007). The challenge of obesity in the WHO European Region and the strategies for response.Copenhagen, Denmark, WHO European Region.

9. Burrows,T. Truby, H.Morgan, P. J.Callister, R. Davies, P. Collins, C. E (2012). "A comparison and validation of child versus parent reporting of children's energy intake using food frequency questionnaires versus food records: Who'san accurate reporter?" Journal of clinical nutrition 11(006).

10. Chen, S.Binns, C. W, Maycock, B. Zhao, Y.Liu, Y. (2014)."Chinese mothers'perceptions of their child's weight and obesity status." Asia Pac J Clin Nutr 23(3): 452-458.

11. Claire, M. Stella K ,Francis Lucy-Joy, Wachira, Allana G. LeBlanc (2014). "Evidence of an Overweight/Obesity Transition among School-Aged Children and Youth in Sub-Saharan Africa: A Systematic Review" plos One 9(3): 9.

12. Daniels, S. Arnett,D.K, Eckel, R. H. (2005). "Overweight in Children and Adolescents Pathophysiology, Consequences, Prevention, and Treatment downloaded from http://circ.ahajournals.org/ (on last june 2015."

13. Davey Smith, G. Steer, C. Leary, S. Ness, A. (2007). "Is there an intrauterine influence on obesity? Evidence from parent child associations in the Avon Longitudinal Study of Parents and Children (ALSPAC). ." Arch Dis Child 92(10): 876-80.

14. De Onis, M. Blo“ssner, M.Borghi, E.(2010). "Global prevalence and trends of overweight and obesity among preschool children1-4" Am J Clin Nutr 92: 1257-64.

15. Dubois, L. and M. Girard (2006). "Early determinants of overweight at 4.5 years in a population-based longitudinal study" International Journal of Obesity (30): 610-617.

16. Duncan, D. T, Hansen, A. R.Wang, W.Yan, F.Zhang, J (2015). "Change in Misperception of Child's Body Weight among Parents of American Preschool Children." Childhood Obesity 11(3).

17. Dupuy, M., Godeau, E.Vignes, C. Ahluwalia, N.(2011). "Socio-demographic and lifestyle factors associated with overweight in a representative sample of 11-15 year olds in France." BMC 11(442).

18. Francis, D. K, Van den Broeck, J.Younger, N. McFarlane, S.(2009). "Fast-food and sweetened beverage consumption: association with overweight and high waist circumference in adolescents." Public Health Nutrition 12(8): 1106-1114.

19. Françoise, M. and Cachera.R,(2011). "Childhood obesity: current definitions and recommendations for their use." International Journal of Pediatric Obesity(6): 325-331.

20. Freire, W. B.,Silva-Jaramillo, K. M. Waters, W. F. (2014). "The double burden of undernutrition and excess body weight in Ecuador" American Journal of Clinical Nurition 100: 1636S-43S.

21. George, A. and Gray D. S.(2005). "pathophysiology of obesity." West J Med 149: 429-41.

22. Gewa, C. A. (2009). "Childhood overweight and obesity among Kenyan pre-school children: association with maternal and early child nutritional factors." Public Health Nutrition 13(4): 496-503.

23. Gibson, A. (2005) Text book of Nutrition $5^{\text {th }}$ Edition page 222-227.

24. Gopinath, B., , Baur, L. A.Burlutsky, G.Robaei, D.Mitchell, P.(2012). "Socio-economic, familial and perinatal factors associated with obesity in Sydney schoolchildren" Journal of Paediatrics and Child Health 48: 44-51.

25. Ip, Stanley., Chung, M. Y. Raman, G .(2007). "Breastfeeding and Maternal and Infant Health Outcomes in Developed Countries." Tufts-New England Medical Center Evidence-Based Practice Center 7(153).

26. Kaufman-Shriqui, V.,Fraser, D. Friger, M. Bilenko, N. Vardi, H. (2013). "Factors associated with childhood overweight and obesity among acculturated and new immigrants." ethinicity and disease 23: 329-335.

27. Kautiainen, S., Koivusilta.L,Lintonen, T. Virtanen, S. M.,Rimpela, A. (2005). "Use of information and communication technology and prevalence of overweight and obesity among adolescents" International Journal of Obesity 29: 925-933.

28. Kostecka, M. (2014). "Eating habits of preschool children and the risk of obesity,insulin resistance and metabolic syndrome in adults." Pak J Med Sci 30(6): 1299-1303.

29. Llewellyn, C. H., van Jaarsveld, C. H. Boniface, D.Carnell, S.Wardle, J. (2008). "Eating rate is a heritable phenotype related to weight in children. ." Am. J. Clin.Nutr. 88(6): 1560-6.

30. Matthews, V. L., Wien, Wien, M. Sabaté, J. (2011). "The risk of child and adolescent overweight is related to types of food consumed." Nutrition journal 10(71).

31. McCarthy, K.,Ye, Y.Yuan, S. He, Q.C (2015). "Parental Weight Status and Offspring Cardiovascular Disease Risks: a Cross Sectional Study of Chinese Children." Prev Chronic Dis 12(140384).

32. Mohammed, H. and Vuvor.F. (2012). "prevalence of childhood overweight /obesity in basic school in Accra " Ghana Medical Journal 46(3).

33. Monteiro, P. O. and Victora .C. G. (2005). "Rapid growth in infancy and childhood and obesity in later life a systematic review." Obes Rev (6): 143-154.

34. Musa, D., A. Toriola, et al. (2012). "Prevalence of childhood and adolescent overweight and obesity in Benue 
State, Nigeria." Tropical Medicine and International Health 17 (11): 1369-1375.

35. Musa, W. A. and Hassan M. K. (2010). "Overweight and Obesity among preschool children in Basrah." medical journal of Basrah University 28(1).

36. Musaiger, A. O. (2011). "Overweight and Obesity in Eastern Mediterranean Region: Prevalence and Possible Causes, Review Article " Journal of obesity.54(67)

37. NIH (2009). over weight and obesity statistics data from national health and nutrition examination survey. N. f. s. USA department of health and human service.

38. Ostojic, S. M. , Stojanovic, M. D. Milosevic, Z. Jorga, J. Grujic, S. (2012). "Prevalence of Obesity and Association between Body Fatness and Aerobic Fitness in Serbian Preschool Children “

39. Ponce, X. Ramirez, Delisl, H. (2006). "A More Diversified Diet among Mexican Men May Also Be More Atherogenic1,2." Journal of nutrition 136: 2921-2927.

40. Raj, M. (2012). "Obesity and cardiovascular risk in children and adolescents; Review Article." Indian Journal of Endocrinology and Metabolism 16(1): 13-19.

41. Ramirez-Zea, M. Kroker-Lobos, M. F. Close-Fernandez, R. Kanter, R. (2014). "The double burden of malnutrition in indigenous and nonindigenous Guatemalan populations" American Journal of Clinical Nutrition 100(suppl)(1644S-51S).

42. Reilly, JJ.Armstrong. J. Dorosty, A. R .Emmett, P. M. Ness, A. Rogers, I. (2005). "Avon Longitudinal study of parents and children study Team. Early life risk factors for obesity in childhood cohort study. . BMJ 330(7504): 1357.

43. Safiya, G., Shaker, R. H.M. Yosef, D. O. 1. (2014). "Obesity Among Primary School Children: Associated Social, Dietary And Behavioral Factors, Kafr Sakr District, Sharkia Governorate Egypt, 2012/2013 " The Egyptian Journal of Community Medicine 13(1).

44. Saker, M., Merzouk, H . Merzouk, S .Ahmed, S.Narce, M. (2011). "Predictive Factors of Obesity and their Relationships to Dietary Intake in Schoolchildren in Western Algeria" Journal of Clinical Medicine 6(2).

45. Santaliestra-Pasías, A. M. Rey-López, J. P.Moreno, L. A.(2013). "Obesity and sedentarism in children and adolescents: What should be done?" Nutr Hosp 28(5): 99-104.

46. Sattar, N.Connachie, A.MC .Shaper, A. G. Blauw, G. J Buckley, B. M (2008). "Can metabolic syndrome usefully predict cardiovascular disease and diabetes? Outcome data from two prospective studies" Lancet 371(1927-35).

47. Senbanjo, I. O. and E. A. Adejuyigbe (2007). "Prevalence of overweight and obesity in nigerian preschool children " Nutrition and Health 18: 391-399.

48. Singh, R. (2013). "Childhood obesity: An epidemic in waiting? Review article." International Journal of Medicine and Public Health 3(1): 5.

49. Strasburger, V. C. (2011). "Policy Statement-Children, Adolescents, Obesity,and the Media." American acadamy of pediatrics $128(1)$.

50. Tabesh, H.,Hosseiny, S. M. Kompani, F. Saki, A.Firoozabadi, M. S.(2014). "Prevalence and Trend of overweight and obesity among Schoolchildren in Ahvaz,Southwest of Iran." Global Journal of Health Science $6(2)$.

51. Torrance, B., K. McGuire, et al. (2007). "Overweight, physical activity and high blood pressure in children: a review of the literature." Vascular Health and Risk Management 3(1): 139-149.

52. VanHook, J.Altmana, C.Balistreri, K. S). "Global Patterns in Overweight Among Children and Mothers in Less Developed Countries." Public Health Nutr. 16(4): 573-581.

53. Veldhuis, L., I. Vogel, et al. (2012). "Behavioral risk factors for overweight in early childhood; the 'Be active, eat right' study" International Journal of Behavioral Nutrition and Physical Activity 9(74).

54. Veldhuis, L. Vogel, I. Renders, C. Van Rossem, L.Oenema, A.HiraSing, R. A. et al. (2006). "Soda Consumption and Overweight Status of 2-Year-Old Mexican-American Children in California" OBESITY 14(11).

55. Whitaker, K. L.Jarvis, M. J.Beeken, R. J.Boniface, D.Wardle, J. (2010). "Comparing maternal and paternal intergenerational transmission of obesity risk in a large population based sample. ." Am J Clin Nutr 91(6): 1560-7.

56. WHO (2006). "WHO Child Growth Standards based on length/height, weight and age." Acta Paediatr (Suppl)(450): 76-85.

57. WHO (2009). Global health risks: Mortality and burden of disease attributable to selected major risks.world Health Organization. Geneva.

58. WHO (2013). "Obesity facts from http://www. who.int/ mediacentre /factsheets /fs311/ en / index.html (last accessed on June2 2015)."

59. WHO (2015). "Available from: http://www.who.int/mediacentre/factsheets/fs311/en/in dexhtml. [Last accessed on 2015, June3]".

60. Wijtzes, A. I. Jansen, W. Franco, O. H.Hofman, A.Jaddoe, V. W. Raat, H. (2014). "Sedentary behaviors, 
physical activity behaviors, and body fat in 6-year-old children: the Generation R Study" International Journal of Behavioral Nutrition and Physical Activity 11(96).

61. Wolde, T. and T. Belachew (2014). "Prevalence and Determinant Factors of Overweight and Obesity among Preschool Children Living in Hawassa City, South Ethiopia." Food Science and Quality Management 29. 